\title{
フーリエ変換赤外分光法 (FT-IR)
}

\section{1.はじめに}

赤外分光法は, 炭素材料そのものの評価上りも, 炭素 前駆体である有機物の化学構造の評価に主に用いられて いる。乙れは, 同じ振動分光法であラマン散乱法が, グ ラファイトの結晶性の評価にしばしば利用されている一 方, 炭素前駆体の化学構造の評価には, ほとんど使われ ていないのと相補的である ${ }^{1)}$ 。炭素自身の評価に赤外分 光法があまり用いられていないのは, $700 \sim 800^{\circ} \mathrm{C}$ 以上 亿熱処理した炭素前駆体は, 巨視的な電気伝導性を示す ようになり, 赤外線吸収スペクトルの測定が著しく困難 となる事情を反映したあのであろう。一方, 炭素材料の 構造や性質は，「生まれと育ち」で決まるといわれるよ うに, 炭素前駆体の構造とその处理過程に強く依存する。 この点からは, 炭素前駆体の評価も炭素材料の評価の一 部とみなせる。また最近では, 赤外分光法を炭素材料表 面の官能基の定性や定量に応用する試み屯行なわれてい る。

本稿に扔いては，ピッチ類に代表される炭素前駆体を 赤外分光法で評価する場合の原理的な問題点について必 要最小限の範囲で触れ, 実験方法について主に述べる。 最後に炭素表面の官能基の評価についても多少紹介した い。本講座の主旨に従い, 市販の標準的な分光器と市販 の付属品を用いて行なえる測定方法に内容を限定し, 特 殊な装置を用いる方法については触れない。

\section{FT-IR の標準的な構成と仕様}

FT-IR の原理や分光器の構成等については, 既にす ぐれた教科書が多数出版されているので, ててでは本稿 で必要な最低限の項目について簡単に触れるにとどめる。 詳しい内容を理解したい読者は，たとえば，文献 2)，3） を参照してあらいたい。また, 分光器の具体的な操作方 法については, 各装置の取扱い説明書を読んであらいた い。

FT 型分光器と分散型分光器の原理上の差は, 分散型 分光器がその名のごとく分散素子 (プリズムや回折格子)

(株) 神戸製鋼所技術開発本部 化学研究所石炭化学研究 室：テ651 神戸市中央区脇浜町 $1-3-18$
鈴木哲雄・西澤 節

を用いて光を分解し，各波数でとに光の強度を測定して スペクトルを得ているのに対して, FT 型分光器では, 光の全エネルギーの干渉に上る変化（インターフェログ ラム）を測定し，それをフーリエ変換という数学的处理 によりスペクトルに変換している点にある(Fig.1 参照)。 FT 型の利点は，測定すべき波数範囲を同時に測定でき る (Fellget Advantage), 分散型分光器のスリットに 比べて面積の大きいダイアフラムを用い，加えて立体角 を大きくできるために, 光束の利用効率が高い(Jacquinot Advantage), レーザーを波数標準としてインター フェログラムのサンプリングを行なうために波数精度が 高い (Connes Advantage) に代表される。乙れらの利 点が, 分散型分光器では実用性の低かった種々のサンプ リングテクニックの自由な応用を可能にし，測定対象の 大幅な拡大をあたらしたのである。FT型分光器のあう 一つの特徵は, フーリエ変換を行なうために分光器自体 が電子計算機を内蔵しなければならず，信号の積算，吸 光度の計算, 差スペクトルの計算, ピークの検出等, フ ーリエ変換以外の種々のデーター処理も内蔵の電子計算 機を利用して行なえることである。今日の FT - IR の普 及には，マイクロエレクトロニクスの発達が不可欠であ
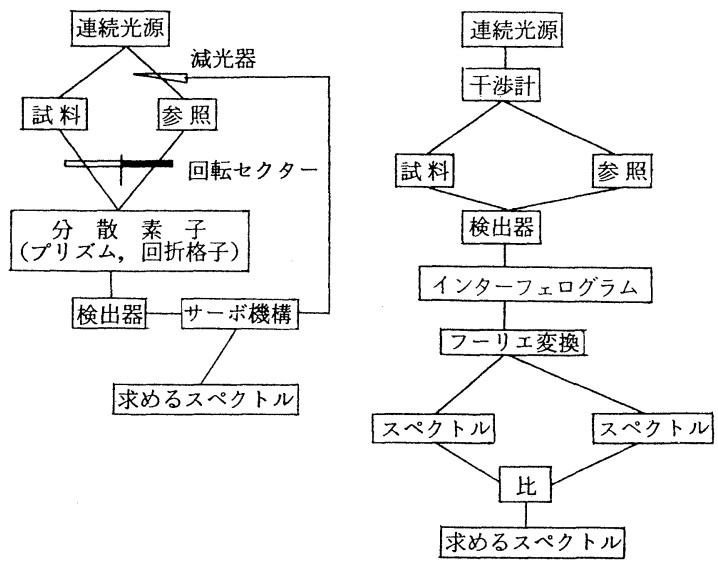

分散型分光器

Fig. 1 分散型分光器と FT 型分光器の原理的な差を 表わした模式図 
ったといえる。

FT - IR 分光器の標準的な構成は, Fig. 2 のようにな っている。分散型分光器と異なり, 基本構成はシングル ビームう式である。ただし, 試料室には鶁料側と参照側 の 2 本の光路があり, 鏡により光路を切り替えることが できるようになっている。光路を一定の積算回数でとに 父百に切り替えながらデーターを採取するてともでき， 透過法による测定では分散型分光器のダブルビーム方式 に準じた測定を行なえる。このような測定法をデュアル ビーム法と呼ぶことあある。

大気中に含まれている水と二酸化炭素は, 赤外領域に 蛞い吸収をもつので, 赤外スペクトルの測定のじゃまに なる。Fig. 3 は, 光源のスペクトルであるが, 分光器の 光路中に含まれている水と二酸化炭素の吸収が現われて いるのがわかる。これらの吸収による妨害を減らすため に, 通常の分光器では内部を乾燥空気で置換できる設計 になっている。また，デュアルビーム法等を用いるとと により見かけ上てれらの吸収を相殺できるが，てれらの

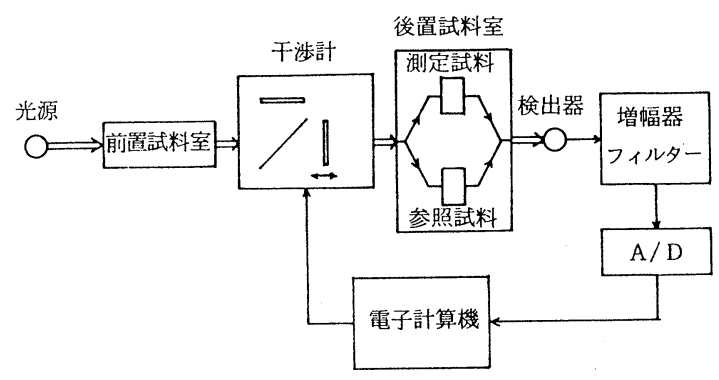

Fig.2 FT-IR 分光器の基本構成

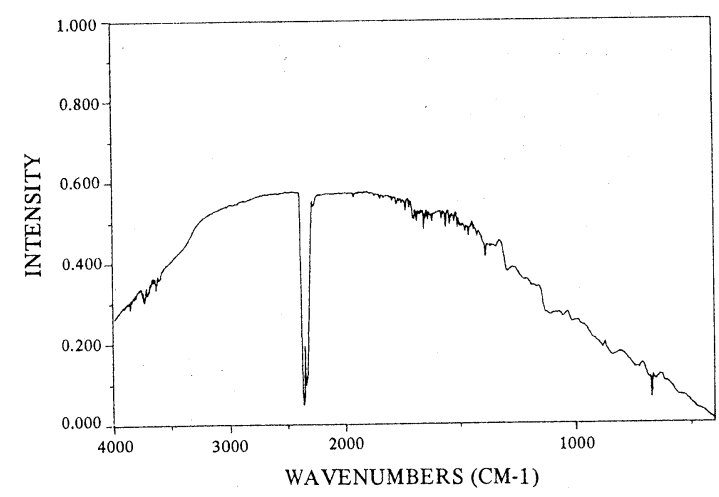

Fig.3 光源のスペクトル

検出器: TGS 分解能 : $4 \mathrm{~cm}^{-1}$ 積算 : 1 回 水と二酸化炭素の吸収が見える
吸収のある領域においてスペクトルの微妙な変化を議論 する場合には注意を要する。

検出器は, 焦電素子である TGS(Triglycine Sulfate) が普及型の分光器ではよく使われているが, 高感度の半 導体検出器 MCT (Mercury Cadmium Telluride) を 使えるようになっているものあ多い。ピッチ類の通常の 測定では, TGS 検出器で十分である。光の強度が弱く なる場合や，高速度でサンプリングを行ないたい場合に は, 高感度で高応答速度の MCT を用いると効率的であ る。

Fig. 4 亿TGS と MCT の雑音特性を示す。同じ強度 の光を二種類の検出器で検出し, 透過率に現われる雑音 を比較した。いずれも積算回数は，10回である。2,000 $\mathrm{cm}^{-1}$ において TGS では雑音が $1 \%$ 程度であるのに対 して，MCTでは $0.1 \%$ 程度である。なお，MCT では， $600 \mathrm{~cm}^{-1}$ 以下の領域は, 検出感度がないために測定でき ない。

(a)

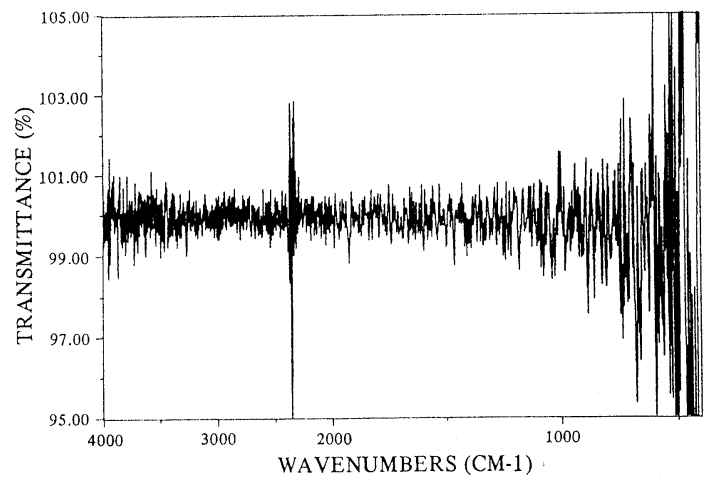

(b)

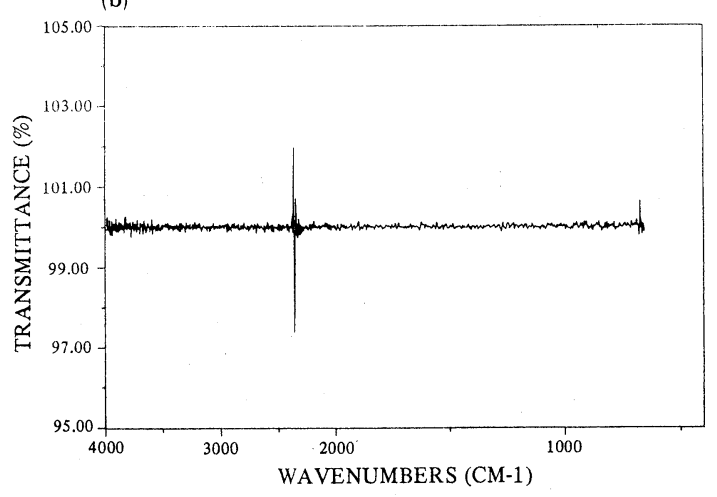

Fig.4 TGS と MCT の雑音の比較

MCT 検出器が飽和しないように光源強度を 減衰させた。分解能 : $4 \mathrm{~cm}^{-1}$ 積算 : 10 回

(a) TGS 検出器を用いて測定した透過率 $100 \%$ の基線

(b) MCT 検出器を用いて測定した透過率 $100 \%$ の基線 
雑音がランダムであるならば，積算による $\mathrm{S} / \mathrm{N}$ の向 上は，積算回数を $\mathrm{n}$ とすると $\sqrt{\mathrm{n}}$ に比例する。Fig. 5 に は, TGS 検出器を用いて積算回数を增やしていった場 合に透過率に現わ扎る雑音が減少していく様子を示す。 この積算回数の範囲では，ほほ $1 / \sqrt{\mathrm{n}}$ に比例して雑音 が減少していることがわかる。原理的には，積算回数を (a)

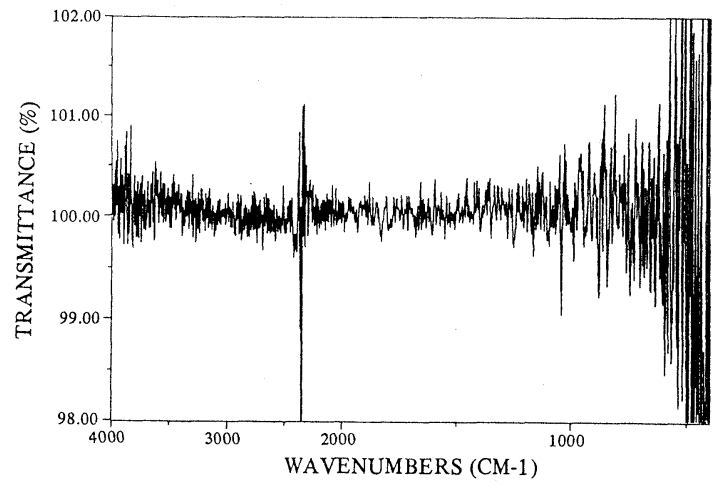

(b)

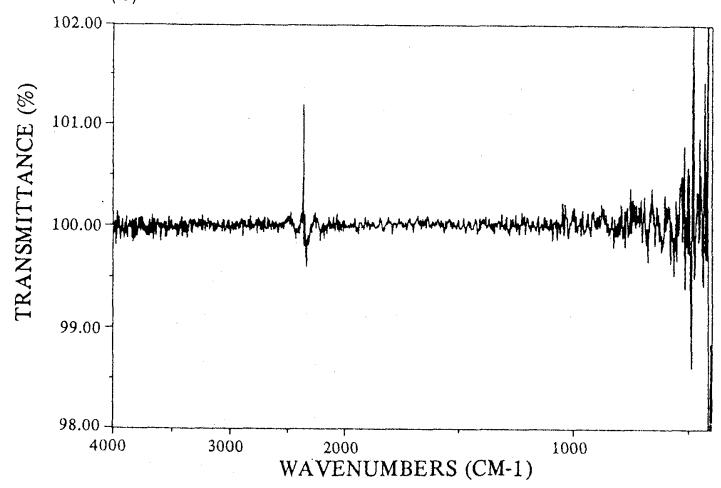

(c)

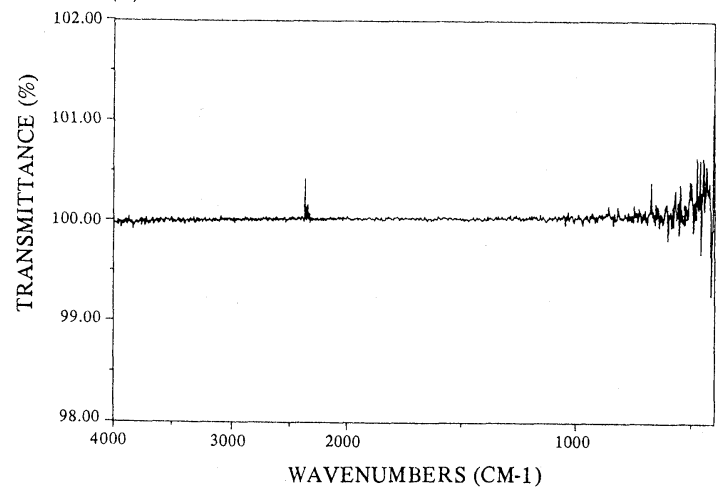

Fig. 5 積算回数と透過率 $100 \%$ 基線に現われる雑 音の大きさとの関係

検出器: TGS 分解能: $4 \mathrm{~cm}^{-1}$
(a) 積算：1回 (b) 積算: 10回
(c) 積算: 100回

増加させれば限りなく $\mathrm{S} / \mathrm{N}$ は向上していく。しかし， 現実には, 積算による $\mathrm{S} / \mathrm{N}$ の改善は，10倍程度までは 容易に行なえるが，100 倍以上改善することは測定時間 からだけであ難しい。さらに，積算によって減少できる のはランダムな雑音だけであり, 装置固有の系統的な雑 音や,ドリフトの影響は残るので，むやみに積算回数を 増やすととは意味がない。

現在市販されている標準的な分光器では, ランダムな 雑音やドリフトの影響屯含めて吸光度にして 0.001 程度 の吸収ならば十分に測定できる水準にある。しかし, 実 際には，試料の調製状態等によりべースラインのゆがみ が生じるために，しばしばこれより測定感度は悪くなっ ている。また，光源強度屯波数依存性を持っており，強 度が小さくなる高波数域と低波数域では検出感度も低下 する。特に, $700 \mathrm{~cm}^{-1}$ 以下の領域で感度の低下が顕著 である。

分光器の仕様としては, 測定波数範囲 $400 \sim 4000 \mathrm{~cm}^{-1}$, 分解能 $2 \mathrm{~cm}^{-1}$, 波数精度 $0.01 \mathrm{~cm}^{-1}$ 程度のむのが市販さ れており，ピッチ類の測定には十分である。

\section{FT-IR によるピッチ類の測定}

ピッチ類を赤外分光法を用いて評価しょうとする場合, 普通の有機物の評価にくらへてて難しい点は, 第一に，ピ ッチ類が複雑な縮合多環芳香族化合物の混合物であるて 之, 第二に,「黒もの」と呼ばれているように色が黒く 可視光領域に強い吸収をあつために，赤外光に対してあ 屈折率が高く反射が強いことである。

第一の問題は，ピッチ類を対象とする限り本質的なす のであり, 赤外分光法固有のあのではない。むしろ, 赤 外分光法では, 特性吸収帯を通して複雑なむのを官能基 という比較的単純化した面で切断してみているだけ，定 性的な評価では有利であると考えられる。一例を Fig.6 に示す。Fig. 6 は, 石油系ピッチ (A 240) とエチルベン ゼンの CH 伸縮振動領域を表わしたあのである。エチル ベンゼンでは， 5 個の芳香族 $\mathrm{CH}$ と 5 個の脂肪族 $\mathrm{CH}$ の 振動が相互作用のために複雑な構造を示している。乙れ に対して石油系ピッチでは，個々の分子の複雑な吸収が 多数重なりあって, 全体としては, 大雑把に, $3000 \mathrm{~cm}^{-1}$ 以上の芳香族 $\mathrm{CH}$ の伸縮振動之, $3000 \mathrm{~cm}^{-1}$ 以下の脂肪族 $\mathrm{CH}$ の伸縮振動とに分加れるだけである。なお，Fig. 6b 石油系ピッチのスペクトルは拡散反射法(後述)で測定し, K-M FUNCTIONで表示している。 K-M FUNCTION 表示は，透過法で測定したスペクトルのABSORBANCE 表示に対応する。

てれまでのとてろ，ピッチ類の特性吸収帯の帰属につ いて議論している文献は少ないが, 石炭については Brown 
(a)

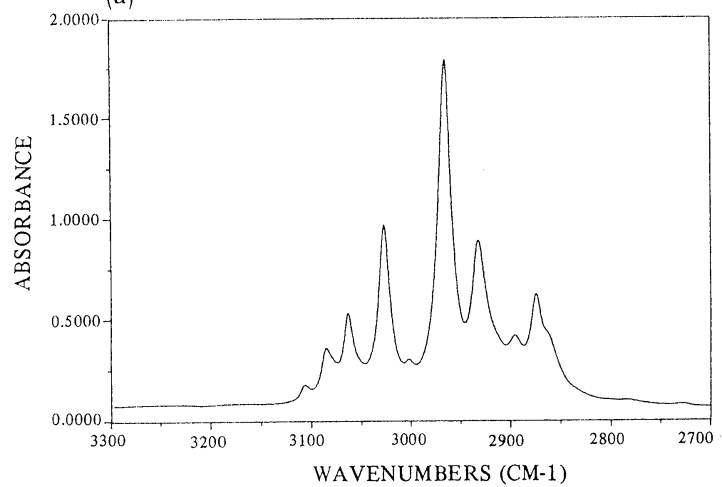

(b)

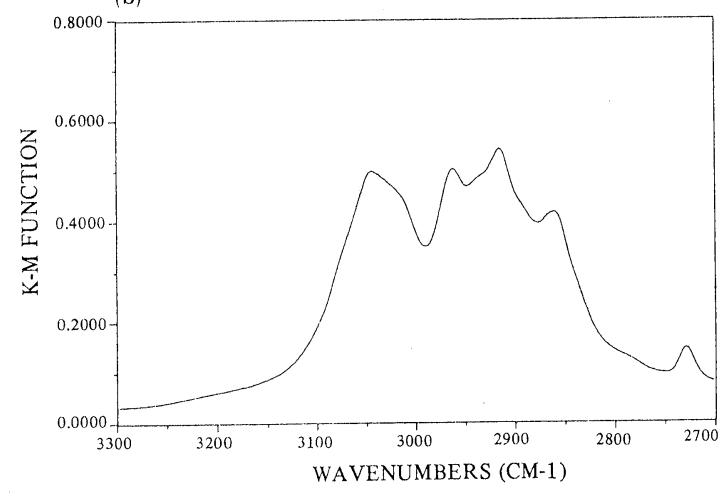

Fig.6エチルベンゼン(a)と石油系ピッチ（A 240）(b) の $\mathrm{CH}$ 伸縮振動領域のスペクトル

の論文 ${ }^{4)}$ 以降, 多くの研究者によって議論されている。 1970年でろまでの研究は, Speight の総説 ${ }^{5)}$ によめら れている。あう少し新しいあのでは, Painter らの論文 6)がある。石炭はピッチに比べて, ヘテロ元素が多く, また，無機成分を多量に含むという培いがある。しかし， 有機成分の特性吸収带の帰属については, 両者の間で大 きく食い違うことはないと考えられる。乙れまでの報文 に基づいてまとめた代表的な特性吸収帯の帰属を,Table 1 亿示す。乙れらの帰属は, 主として類似する有機化合 物の吸収 ${ }^{7) 8)}$ からの類推と, 石炭の化学処理によるスペ クトルの変化から決められたあのである。Table 1 亿あ げた州属は, 個別に詳細をみるとまだ多くの問題を含ん でいる。たとえば, $1735 \mathrm{~cm}^{-1}$ 付近の吸収は, 芳香族力 ルボン酸にあエステルにもピークの位置からはどちらに 屯帰属できる。乙のような場合の帰属には, 試料の処理 履歷を考慮した検討が必要である。また，1100～ 1300 $\mathrm{cm}^{-1}$ の領域には, C-O 伸縮振動以外にも, 吸収を示す あのが多く,さらにての領域の吸収は回りの置換基の影 響を受けて幅が広がっているため，乙の領域の吸収の帰 属には特に注意を要する。
Table 1. ピッチ類の特性吸収帯の帰属 ${ }^{5) 6) 7) 8 ~}$

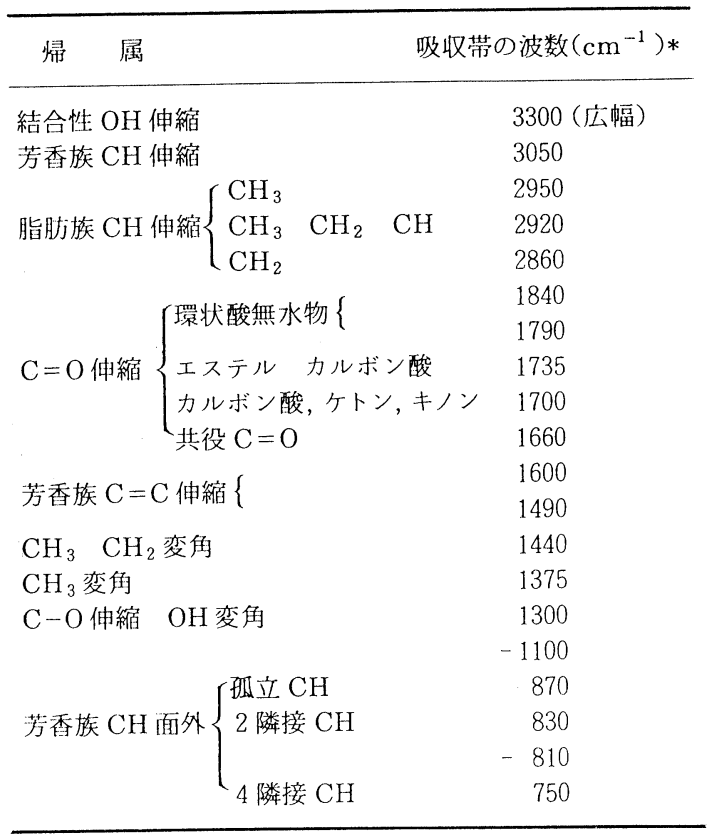

*代表的な値， $10 \mathrm{~cm}^{-1}$ 前後ずれる場合もある。

赤外分光法では，特性吸収帯に注目することにより， 問題としているピッチ類の中にどんな官能基が存在して いるのかということを，定性的あるいは半定量的につか むととができる。しかし, 注目している官能基がどの程 度存在しているのか, 赤外分光法で定量的に評価するて とは難しい。それは, ピッチ類が種々雑多な分子の混合 物であるために, 原理的に物質固有の量である分子吸光 係数に相当するものを定義できないということと, 実験 的に絶対吸収強度の測定が難しいという二つの理由から である。赤外分光法によるピッ千類の定量的評価法で, ある程度実用になっているあのは, 同一スペクトル内で の特性吸収帯間の相対強度を用いる場合に, ほとんど限 られているようである。たとえば, 芳香族と脂肪族の $\mathrm{CH}$ 伸縮振動の強度から, 芳香族指数を見積るというょうな 場合である ${ }^{9)-11) 。 ~}$

定量的な評価ということでは, スペクトルの強度が原 子核の数に比例するNMRのほうが有利である。しかし， 測定対象の広さという点からは赤外分光法の方が優って 扔り, 将来的には赤外分光法による官能基の定量的評価 ああう少し実用になっていくと思われる。

ピッチ類を赤外分光法を用いて評価する場合の第二の 問題, すなわち色が黒く屈折率の大きい試料のスペクト ルをどのようにして測定するかが，ある意味では本稿の 
中心テーマであるといえる。乙の点については, 従来の 分散型分光器に比べて, FT-IR の威力が大いに発揮さ れている。以下，乙れを解決するための具体的な測定方 法について述べる。

\section{1 透過法}

吸収スペクトルを求める最む簡便な方法は, 入射光強 度, $\mathrm{I}_{0}(\nu)$, と透過光強度, $\mathrm{I}(\nu)$, を測定し, 透過率, $\mathrm{I} / \mathrm{I}_{0}$, 吸光度, $1 \mathrm{n}\left(\mathrm{I}_{0} / \mathrm{I}\right)$ ， 亿換算することである。純 物質では, 吸光度を, 単位光路長当たり, 単位濃度当た りの分子吸光係数们換算して強度を議論する。しかし， 種々雑多な分子が混ざっているピッチ類では，そてまで 絶対強度を議論した例はほとんど見当たらない。透過法 の実験上の問題点は, 光の吸収を入射光と透過光の強度 刀差として求めているため, 吸収以外の反射や散乱で透 過光が弱められた場合に, 吸収と区別できないとてろに ある。

\subsubsection{NEAT 法}

NEAT 法は, 液体状の試料をそのまま赤外光を透過 する空材ではさんで, 透過法で吸収スペクトルを測定す る方法である。ピッチ類であ, へキサン可溶成分程度の 軽質分は, 室温で液体状態あるいは流体状であるので, ての方法を応用できる。恕材としては, 低波数領域での 透過特性がよいととから，KBrがよく使用される。一旦 試料をつけた空材は, 洗浄が難しいので, 使いすてがで きる方が望ましい。筆者らは，市販のスペクトル用の $\mathrm{KBr}$ 粉末を $300^{\circ} \mathrm{C}$ で 3 時間程度乾燥させた後, 錠剤成形 用のプレスで, 厚さ $1 \mathrm{~mm}$, 直径 $10 \mathrm{~mm}$ 程度の円盤に成 形したものを空板として利用している。ある程度粘度が 高く, 測定中に流机出さないような試料をうすく均一に 塗り付けただけで測定できる。参照側に同じ厚さの $\mathrm{KBr}$ 板のみを取り付けて, デュアルビーム法で測定すると， $\mathrm{KBr}$ 自体の吸収を相殺でき試料による吸収だけを測定 できる。この方法で測定した水添コールタールのスペク トルの一例を Fig. 7 亿示す。

ての方法は, 室温で流動性が低くてあ数 $10^{\circ} \mathrm{C}$ に加熱 すれば流動性が高くなる試料に対してあ応用できる。あ らかじめ $\mathrm{KBr}$ 板をホットプレートやドライヤーで暖め て打くと, 試料を薄く均一に塗り付けやすくなる。ただ し，高温で空気にさらした場合に試料が部分的に酸化さ れることああるので注意を要する。

てのような軽質成分の定性分析については,「黒むの」 でも普通の有機物と比べてほとんど実験上の問題はない。 定量分析でむ, 同一スペクトル内で, 吸収帯間の相対強 度を議論する場合には，試料の愿みを注目する吸収帯の 透過率が15\%できれば20\%以上になる上うに調製する以 外, あまり問題はない。透過率が小さい場合には, 吸光

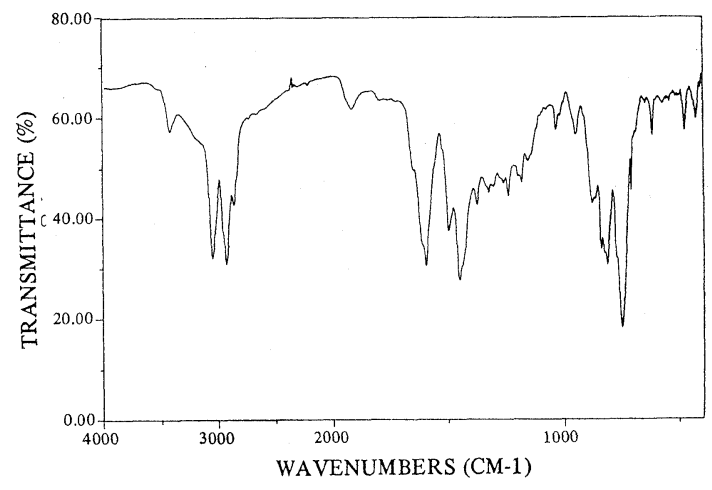

Fig.7 NEAT 法で測定したスペクトルの例 試料: 水添したコールタール 検出器: TGS 分解能: $4 \mathrm{~cm}^{-1}$ 積算: 50 回 スペクトルは透過率表示

度に変換する際に誤差が大きくなる。一方, 絶対量を定 量しょうとすると, 試料の厚さと濃度（量）をきちんと 決めてやらねばならず，本方法では非常に難しい。

\subsection{2 薄膜法}

四塩化炭素や二硫化炭素のような揮発性の溶剤に可溶 な成分については, 薄膜法が応用できる。試料を揮発性 の溶剤にとかし, 溶液を $\mathrm{KBr}$ 板の上に滴下させ溶媒を 乾燥させると, $\mathrm{KBr}$ 板上に均一な試料の薄膜を作るこ とができる。後は NEAT法と同様に, スペクトルを測 定できる。乙の方法では, 溶媒の乾燥が不十分である場 合には，溶媒の吸収が重なって観測される。また，毒性 を持った有機溶剂を使用するので, 試料の調製は十分換 気の良い，できれば局所排気設備のもとで行なうのが望

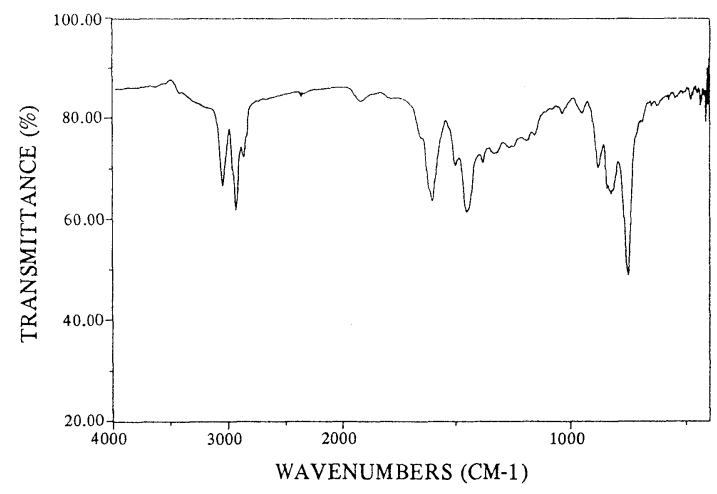

Fig. 8 薄膜法で測定したスペクトルの例 試料 : 水添した石炭系ピッチのベンゼン可溶 成分 検出器: TGS 分解能: $4 \mathrm{~cm}^{-1}$ 積算 : 50回 
ましい。本力法は, NEAT法に比べると試料調製に手 間がかかる。ベンゼンクラスの溶媒に可溶な成分は, 多 くの場合加熱すれば容易に NEAT 法で測定できるので, 筆者らはあまり本方法を使ったととはない。その他の得 失については, NEAT 法と同じである。

本方法を用いて测定した水添コールタールピッチのベ ンゼン可溶成分のスペクトルを, Fig.8亿示す。

\section{1.3. 錠剤法}

錠剂法は，固体状の試料を微粉末にし $\mathrm{NaCl}, \mathrm{KCl}$, $\mathrm{KBr}, \mathrm{CsI}$ などの赤外線を透過しある程度の可塑性を持 つ粉末と混合した後, 錠剤成形用プレスで錠剤にして透 過法でスペクトルを測定する方法である。一般には, $\mathrm{KBr}$ が最むよく使用されている。乙の方法は，古くから粉末 状の有機物や無機物のスペクトルの測定に用いられてき た。溶剤不溶成分を含むピッチ類のスペクトルの測定に あ, 従来は錠剂法が多く使わ机てきた。しかしながら, 錠剂法は試料による散乱の影響を大きく受けるので，「黒 あの」の測定に適しているとは必ずしあいいがたい。

錠剂法で測定する場合には，散乱の影響を少なくする ために理想的には試料を赤外線の波長以下（たとえば 1 $\mu \mathrm{m} ）$ にまで粉砕する必要がある。とてろが，ピッチ類 の場合, 一旦粉砕された粒子が再凝集するために，粉砕 にはかなりの工夫を要する。試料を冷却したり，あるい は，KBrの粉末を加えて希釈したりする方法があるが， 筆者らの経験では乙れらの工夫む十分ではない。

石炭系メソフェーズピッチのスペクトルを例に，ての 辺の事情を紹介する。試料ピッチ（石炭系メソフェーズ ピッチA）は，キノリン不溶分を $18 \mathrm{wt} \%$ ，ベンゼン不 溶分を $86 \mathrm{wt} \%$ 含むあのである。試料ピッチをメノウ乳 鉢で粉砕し, JIS 標準ふるい目開き $44 \mu \mathrm{m}$ を通過したす のを採取する。乙れを $\mathrm{KBr}$ 粉末と混合して, 錠凨にす る。このようにして調製した試料のスペクトルを，Fig， 9 亿示す。乙れは，約 $0.3 \mathrm{wt} \%$ のピッチを含む錠剤で測 定したスペクトルである。Fig.9からわかるように，高 波数側では光の透過が悪く, $\mathrm{CH}$ 伸縮振動はほとんど見 えていない。てれを吸光度に換算したスペクトルと，さ らにベースラインの補正をほどししたスペクトルを Fig. $9 \mathrm{~b}$ に示す。同じ試料を $\mathrm{KBr}$ 粉末と混合しさらに粉砕を 試みた後に，錠剤に成形して測定したスペクトルを Fig， 10亿示す。Fig. 9 亿比べると，いくらか改善はされてい るもののまだ不十分である。また, 粉砝作業中に吸収し たと思わ机る水の $\mathrm{OH}$ 伸縮振動が見える。

ての実例からわかるように, ピッチ類の赤外スペクト ルを $\mathrm{KBr}$ 錠剤法で測定すると, 官能基による吸収より あはるかに大きなバックグラウンドが生じ，特性吸収帯 は非常に観測しにくい。乙のバックグラウンドは，試料

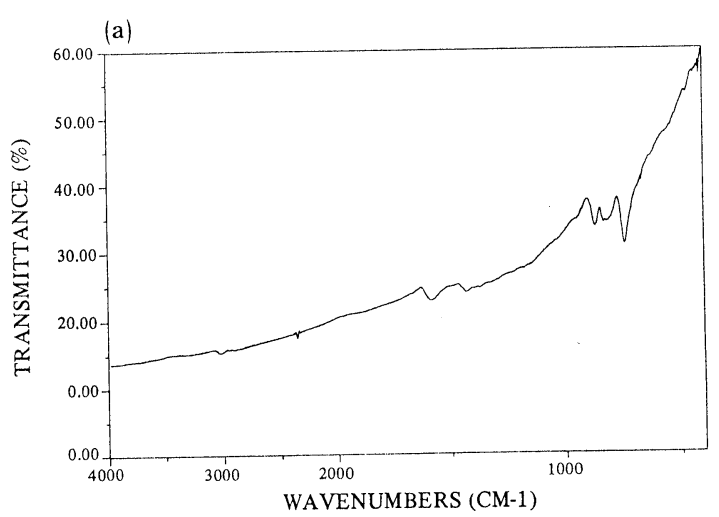

(b)

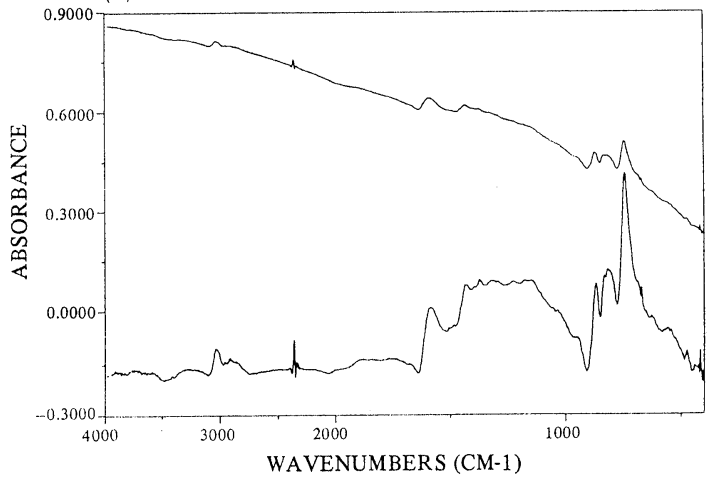

Fig.9 KBr 錠剂法で測定したスペクトルの例 1 試料：石炭系メソフェーズピッチA ( $44 \mu \mathrm{m}$ のふるいを透過したもの), 濃度 0.3 wt \% 検出器: TGS 分解能: $4 \mathrm{~cm}^{-1}$

積算 : 200 回

(a) 透過率表示のスペクトル

(b) 上：吸光度表示のスペクトル下：ベー スラインを補正した後縦軸を拡大したスペ クトル

の粒度, $\mathrm{KBr}$ 粉末との混合状態が変わると大きく変化 すること，また，後に述べる拡散反射法や PAS 法で同 一の試料について測定しても，乙れほど大きなバックグ ラウンドは現われないてとから, 試料自身の連続的な赤 外線の吸収というょりあ, 散乱や乱反射が原因で生じて いると考えられる。

最近，ここで述べた問題点の解決を試みた新しい錠剂 法が貝原らによって提案されている(12)13)。筆者らは彼 らの方法を実際に使用した経験がないので, 評価はさし ひかえる。興味ある読者には, 実際に試してみるととを すすめる。

\section{2 拡散反射法}

拡散反射法は, 粉末試料をよく粉砕してから希釈剂で 適当に希釈し，拡散反射率を測定する方法である。粉末 
(a)

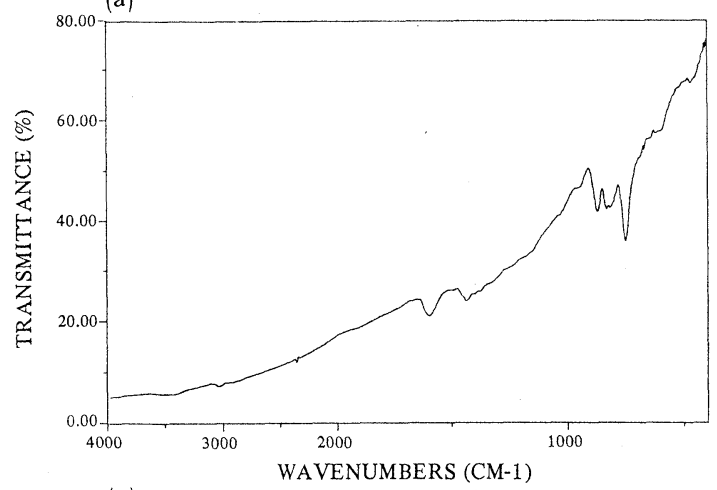

(b)

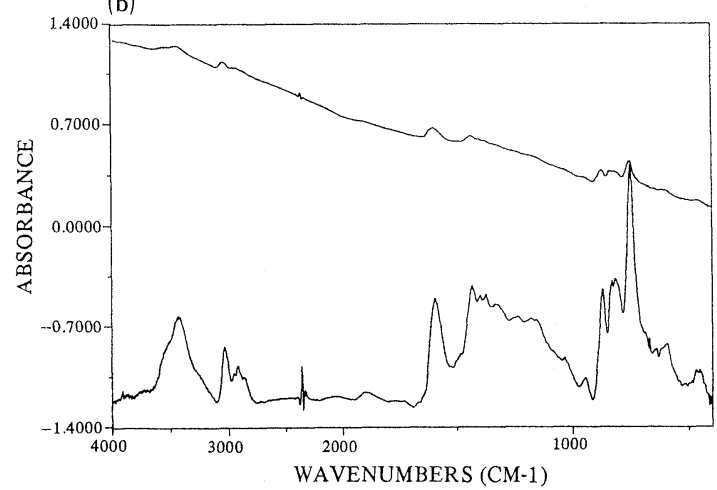

Fig. $10 \mathrm{KBr}$ 錠剂法で測定したスペクトルの例 2 試料：石炭系メソフェーズピッチA $(44 \mu \mathrm{m}$ のふるいを透過したものを $\mathrm{KBr}$ とともにさ らに粉砕した), 濃度 $0.3 \mathrm{wt} \%$ 検出器: TGS 分解能: $4 \mathrm{~cm}^{-1}$ 積算 $: 200$ 回

(a) 透過率表示のスペクトル

(b) 上：吸光度表示のスペクトル 下：ベー スラインを補正した後縦軸を拡大したスペ クトル

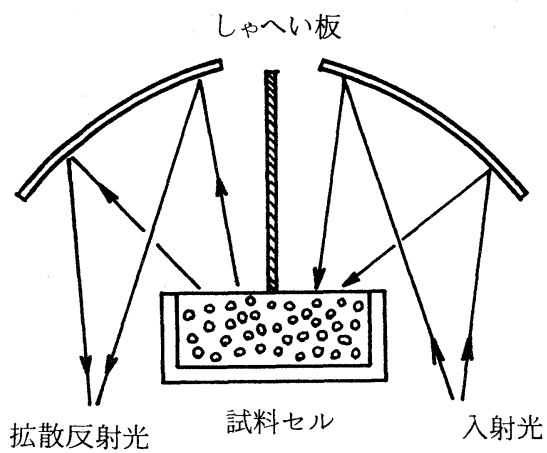

Fig. 11 拡散反射用試料セルの模式図

試料の吸収スペクトルの測定方法として, 拡散反射法は 古くから知られていたが，赤外領域に拀いて実用的に用 いられるようになったのは，FT-IR が出現してからで
ある。拡散反射法の原理については，文献を参照しても らいたい ${ }^{14)}$ 。Fig.11に，試料セルの様子を模式的に示 す。

筆者らの経験では，溶剤不溶分を含むピッチ類の赤外 スペクトルの測定には，3.1で述べた $\mathrm{KBr}$ 錠剤法より 屯拡散反射法が適している。拡散反射法によるスペクト ルの測定は，以下の上うにして行なう。希釈剂 $(\mathrm{KBr}$ 粉 末）の拡散反射スペクトルを測定する。試料を希釈剂で 希釈し，拡散反射スペクトルを測定する。希瀵剤に対す る試料の拡散反射率, (試料の拡散反射スペクトル)/(希 釈剂の拡散反射スペクトル)，を計算する。乙れは，透 過法の場合の透過率にほぼ対応する。拡散反射率を(1)式 にしたがい, Kubelka-Munk 関数に変換する。通常, この変換用のプログラムは，装置に内蔵されている。

Kubelka-Munk 関数は, 吸光度に比例した量になって いる。

$$
f(\nu)=[1-r(\nu)]^{2} /[2 r(\nu)]
$$

ここで, $r(\nu)$ は希釈剤に対する試料の拡散反射率, $\mathrm{f}$

(v) は Kubelka-Munk (K-M) 関数である。

前述の錠剂法で測定した石炭系メソフェーズピッチと 司一の屯のについて，KBr 希釈剤として拡散反射法 でスペクトルを測定した例を Fig. 12 亿示す。試料抢よ

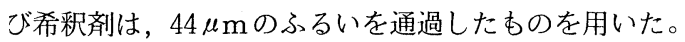
また，試料の濃度は，4 wt％である。Fig. 12aは, KBr 粉末の拡散反射スペクトル, Fig. $12 \mathrm{~b}$ は, 試料の拡散反 射スペクトルである。 $\mathrm{KBr}$ 希釈剤に対する試料の拡散 反射率を，Fig. $12 \mathrm{c}$ 亿示す。乙れを K-M 関数に变換し たものが，Fig. 12d である。Fig. 12c の拡散反射率の 表示では, 相対的に弱い吸収が強調されるので, 弱い吸 収帯の定性評価を行なう場合には，乙の表示の方が便利 なととあある。しかし，吸収帯間の相対強度を議論する ときには, 吸光度に対応する $\mathrm{K}-\mathrm{M}$ 関数に变換しなくて はならない。

拡散反射法では，試料の希釈剂に対する濃度，試料扔 よび希釈剂の粒度が測定されるスペクトルの質に大きな 影響を与えるといわ机てる。乙れらの点について，筆 者らが検討した結果を紹介する。

試料の粒度は，赤外線の波長之同程度以下にするのが 望ましい之教科書等には書かれているが，筆者らの経験 では，JIS 標準ふるい目開き $44 \mu \mathrm{m}$ を透過するまで粉砕 すれば，㥶用上十分なスペクトルが得られている。Fig. 12 で紹介したスペクトルは，既に述べたように，試料掠 よび希釈剂をての粒度まで粉砕して測定したものである。 目開き $44 \mu \mathrm{m}$ のるいを透過しなかった同一の試料につ いて測定したスペクトルを，Fig.13に示す。低波数側で ベースラインが盛り上がったり，吸収帯が多少ひずんだ 

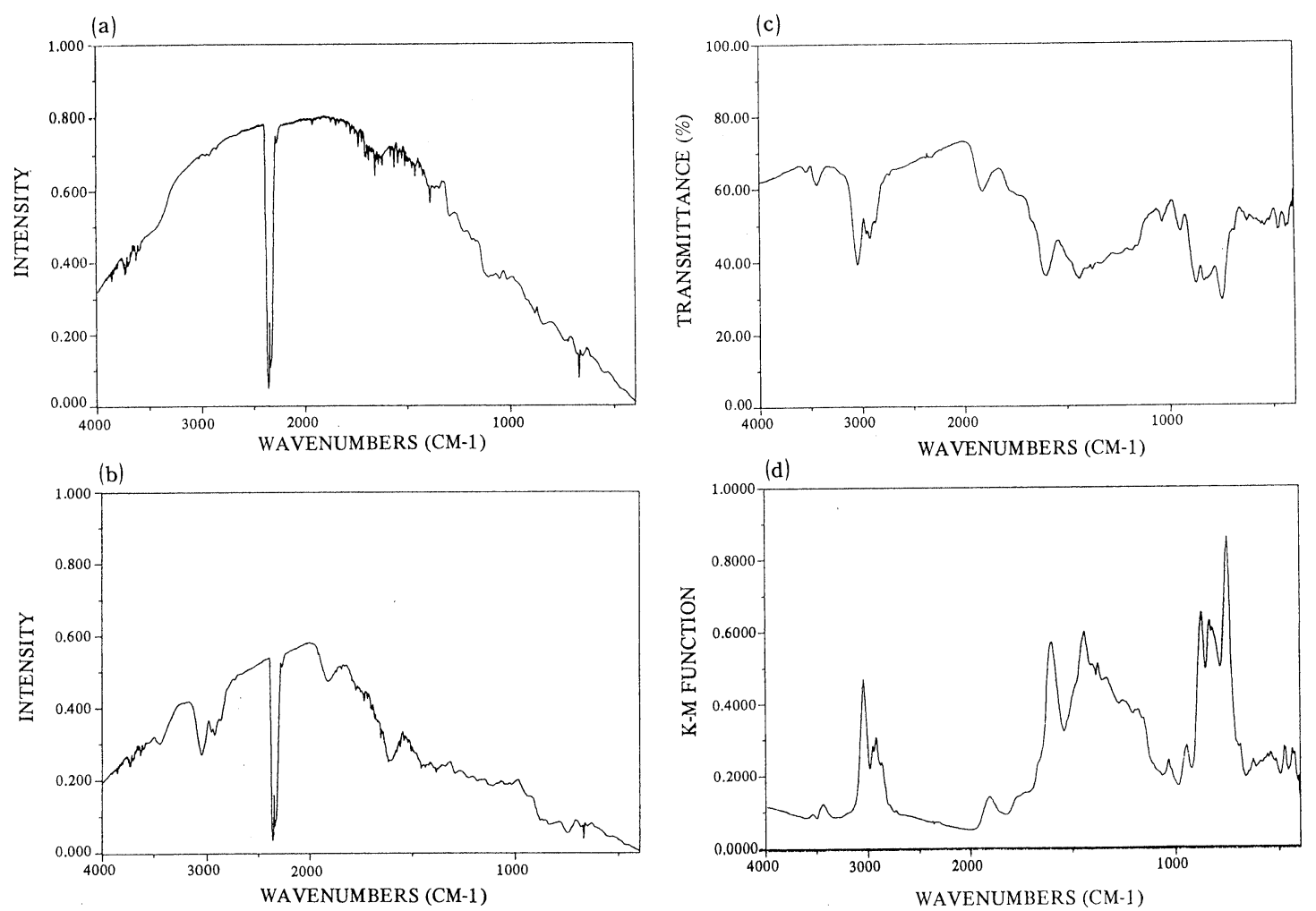

Fig. 12 拡散反射スペクトル測定の実際

試料：石炭系メソフェーズピッチ A $\left(44 \mu \mathrm{m}\right.$ のふるいを透過したもの） 検出器 : TGS 分解能: $4 \mathrm{~cm}^{-1}$ 積算 : 500 回

(a) 希勫剂（KBr 粉末のみ）の拡散反射スペクトル $\quad$ (b) 試料（ $\mathrm{KBr}+$ ピッチ）の拡散反射スペクトル， $\begin{array}{llll}\text { 濃度 } 4 \mathrm{wt} \% & \text { (c) 拡散反射率表示のスペクトル } & \text { (d) Kubelka-Munk 関数表示のスペクトル }\end{array}$

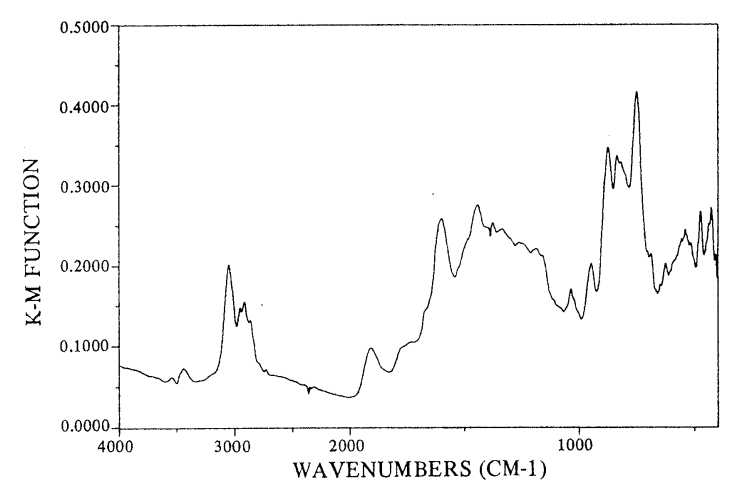

Fig. 13 試料の粒度がスペクトルに与える影響

試料：石炭系メソフェーズピッチ A (44 $\mu \mathrm{m}$ のふるいを透過しなかったもの),濃度 $4 \mathrm{wt} \%$ 検出器 : TGS 分解能 : $4 \mathrm{~cm}^{-1}$ 積算: 500 回

りしているのが認められる。また, Fig. $12 \mathrm{~d}$ のスペクト ルに比べて試料の濃度は同じであるにあかかわらず, 全 体に強度が小さくなっている。希釈剤の粒度む, 大き過 ぎるとベースラインのうねりを生じさせるので, 試料と

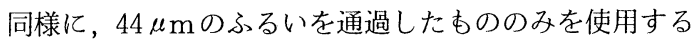
のが望ましい。しかし，目的によっては，ふるいで粒度 をそろえなくても，メソウ乳鉢で十分に粉砕する程度で 実用上支障ないてともある。

試料の希釈剂に対する濃度は，高くなり過ぎると反射 の影響が強くなり，スペクトルの帯形がゆがむことがあ る。濃度が低過ぎると, 希釈剤中の不純物の影響を受け るようになる。石炭系ピッチで調べたとてろ，実用的に は，濃度を0.2 8 wt \%の範囲で変化させても，スペク トルの見かけはほとんど变わらないことがわかった。

Fig. 12 と同じ試料を，濃度 $0.2 \mathrm{wt} \%$ まで薄めて測った スペクトルを，Fig. 14 に示す。両者の間で，相対強度 に若干の差があるが，本質的には同じスペクトルが得ら れている。濃度 $0.2 \mathrm{wt} \%$, 絶対量で約 $0.5 \mathrm{mg}$ 亿対応し ており, 乙の実験は同時に, 拡散反射法では通常量の分 析に拀いて, 数 $100 \mu \mathrm{g}$ 以下の試料でむ十分な $\mathrm{S} / \mathrm{N}$ 比の スペクトルを得られるてとを示している。

拡散反射スペクトルには, 常に反射スペクトルの成分 


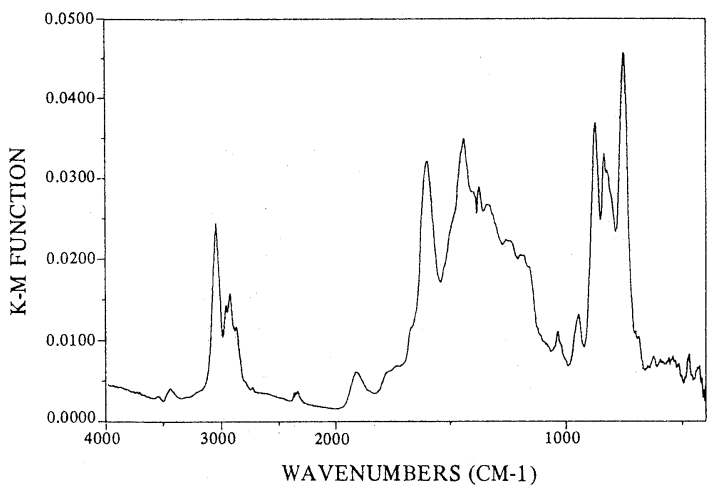

Fig.14試料の濃度がスペクトルに与える影響

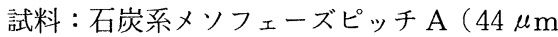
のふるいを透過したもの)，濃度 $0.2 \mathrm{wt} \%$ 検出器: TGS 分解能: $4 \mathrm{~cm}^{-1}$ 積算: 500 回

と吸収スペクトルの成分が重なっている。反射スペクト ルの成分を抑えるために，反射防止板を使用しているが， 筆者らの経験では，あまり大きな効果はないようである。 しかし，念を入れるという意味で実際の測定では，常に 反射防止板を使用している。

次に, 拡散反射法で熱処理ピッチのスペクトルを測定 し，熱处理にともなうピッチ中の官能基の変化を調べた 例を紹介する。前述の方法にしたがって測定した石炭系 メソフェーズピッチの熱処理前後のスペクトルをFig. 15 に示す。熱処理は, 昇温速度 $2.5^{\circ} \mathrm{C} / \mathrm{min}$, 熱処理温度 600 ${ }^{\circ} \mathrm{C}$ で窒素雾囲気中で行なった。Fig. 15 から，熱処理に とあない, 脂肪族水素がほとんど消失していること, 芳 香族水素の脱離も部分的に生じて, 相対的に 4 隣接水素 が減少し孤立水素が増加していることがわかる。屯ちろ ん個々の条件によって多少状況は異なるが，本方法では， 熱処理温度 $700^{\circ} \mathrm{C}$ 程度のピッチ類まで測定の対象になり 得るようである。

これまで, ピッチ類のスペクトルの測定方法として， 拡散反射法が $\mathrm{KBr}$ 錠剂法に比べて有利であるととを述 べてきた。次に拡散反射法の問題点について述べる。拡 散反射法は，ピッチの官能基の定性分析には適している が，定量性には問題がある。筆者らが，拡散反射法を定 量分析に応用しようとして検討したとてろ, 現在までに次 のような結果が得られている。同一試料であセルへの充 填を变えるだけで，見かけの強度が50\%以上屯変化する ことがある。同一スペクトル内の吸収帯間の相対強度は, 近接した吸収帯同士では信頼性の高い結果が得られてい る。筆者らは, 芳香族と脂肪族の $\mathrm{CH}$ 伸縮振動に着目し, ピッチ中の芳香族水素と脂肪族水素の割合を求めるのに 拡散反射スペクトルを利用している ${ }^{11)}$ 。しかし, 吸収帯

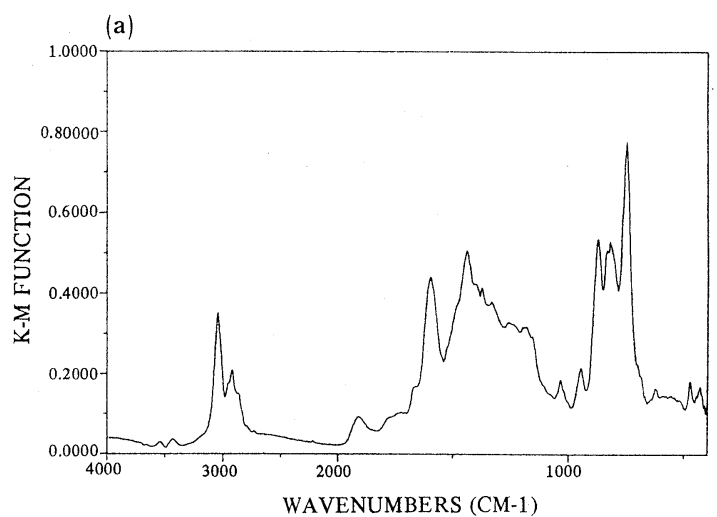

(b)

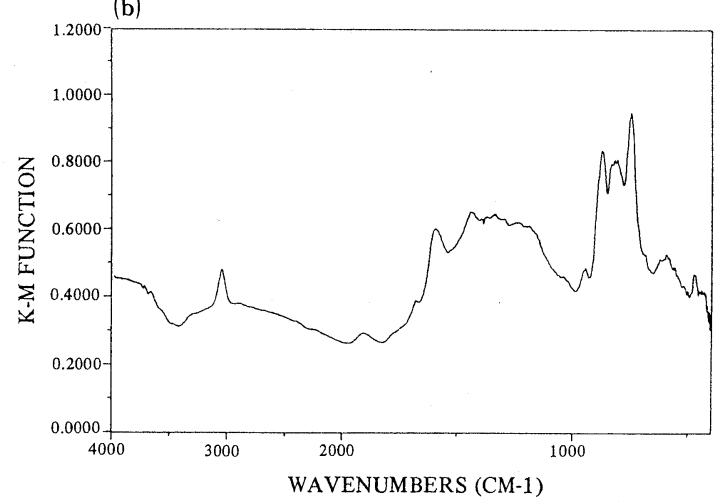

Fig. 15 拡散反射法で測定した熱処理前後でのスペク トルの変化 試料：石炭系メソフェーズピッチ B 検出器: TGS 分解能: $4 \mathrm{~cm}^{-1}$ 積算: 500 回 熱処理条件 昇温速度: $2.5^{\circ} \mathrm{C} / \mathrm{min}$ 処理温度 : $600^{\circ} \mathrm{C}$

(a) 熱処理前のピッチのスペクトル

(b) 熱処理後のピッチのスペクトル

間の相対強度も, 数 $100 \mathrm{~cm}^{-1}$ 以上離れた場合には, 数 10\%程度の再現性しかないようである。

\section{3 PAS 法}

PAS 法は, 光の吸収を音波のエネルギーとしてマイ クロフォンを用いて検出する方法である。試料が吸収し た光のエネルギーは，熱となって試料を暖める。さらに 試料セル中の気体を暖めて，音波を発生させる。乙の音 波のエネルギーを，マイクロフォンを用いて検出する。 以上が PAS 法の基本原理である。本方法では，光の吸 収から信号の検出までの間に，試料中での光から熱への エネルギーの変換, 熱の伝導, 音波の励起と伝播等の過 程がある。そのため，測定されたスペクトルから試料の 吸光係数を求めることは，一般には難しい。しかしなが ら, これらの過程の性質をうまく利用して, 試料の深さ 方向の情報を得ることあできるので興味深い測定法であ 
る。

またPAS 法は，試料の形状にはあまり依存せずに測 定ができる，反射や散乱の大きい試料でも測定ができる， 测定後倵料を回収できるといった利点がある。てのよう な利点にあかかわらず，乙れまでのところ PAS 法は， ピッチや炭素材料の評価にはあまり用いられていない。

篗者らは，PAS 法を用いて石炭系メソフェーズピッ チのスペクトルの测定を試みたととがある。参照試料と して，カーボンブラックを使って測定したスペクトルは， 搪散反射法で得ら机たものと大差なかった。PAS法を用 いて测定したピッチのスペクトルの例を Fig. 16亿示す。 現状では, PAS 法は拡散反射法に比べて, 干渉計の掃 引速度を抢そくする必要があるため, 測定に時間を要す る。したがって, 拡散反射法と同等のスペクトルしか得 られない上うならばあまり魅力はない。今後, 光の吸収 を音波に変換して测定するという, PAS 法の原理をうま く利用した炭素材料の評価技術が開発されるととを期待 したい。特に, PAS 法では, 測定条件を適当に設定する ことにより，試料の表面からの梁さ方向についての情報 を得ることができるので, 炭素材料の表面コーティング の状態評価などに応用できるならば，興味深い。

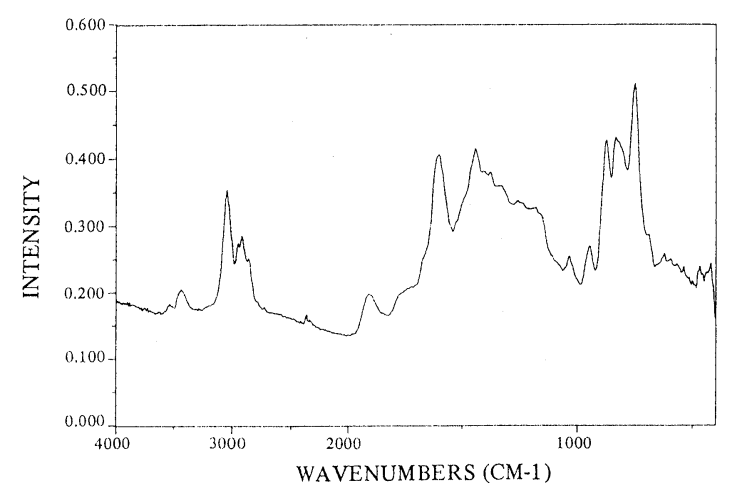

Fig. 16 PAS 法で測定したスペクトルの例 試料 : 石炭系メソフェーズピッチ $\mathrm{A}$ 分解能: $8 \mathrm{~cm}^{-1}$ 積算: 500 回

\section{FT-IRによる炭素材料表面の評価}

赤外分光法は, 特性吸収帯の測定を通して, 化合物中 の官能基の評価に適している。乙の特徴を活用して, 種 々の材料の表面の評価に, FT-IR を応用する試みがな されている。炭素材料に関しても, カーボンブラックや 炭素繊維の表面に依存する官能基の定性や定量分析に FT-IR を用いる試みがなされている。

最近, 石田らは, FT-IR による炭素瀻維表面の評価
に関する研究を意欲的に進めている ${ }^{15)}$ 。彼らは, ATR 法を用いて, 表面处理によって導入した官能基が種々の 化学反応でどのように変化していくのか追跡している。 彼らの実験結果は, かなり努力して調整した分光システ ムを用いて得たあののようであり, 普通の装置を利用す る実験方法の解説という本稿の主旨からはずれる。しか し, 今後は, 乙の方面へ赤外分光法を応用しようとする 動きは, ますます強まっていくと思われるので, 普通の 装置でどの程度のことができるのか筆者らが試みた例を 簡単に紹介したい。きわめて初期的な結果であるが，乙 れに刺激されて「我々ならあっといい結果を出せる」と いう読者が現われることを期待している。

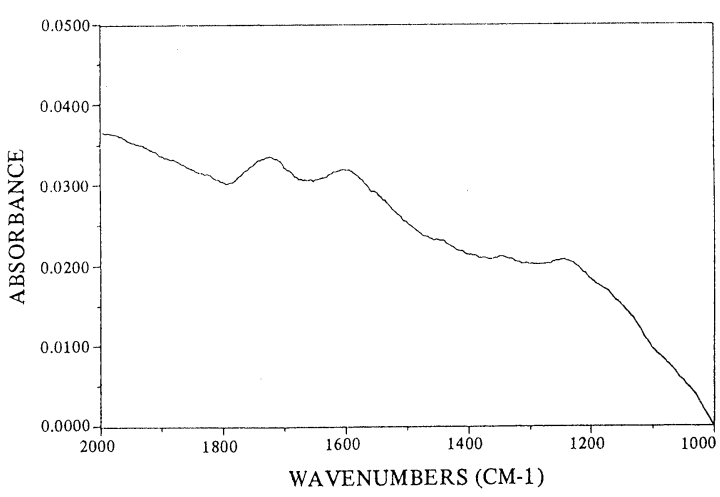

Fig.17 ATR 法で測定したピッチ系炭素繊維の表面 のスペクトル

検出器: MCT 分解能: $4 \mathrm{~cm}^{-1}$ 積算: 500回 硝酸酸化した繊維の ATR スペクトルから未 処理の繊維の ATR スペクトルを差し引いた 差スペクトル

汎用グレードのピッチ系炭素繊維を，60\%硝酸中，90 ${ }^{\circ} \mathrm{C}$ で 4 時間酸化处理し, ての処理によって導入された酸 化構造を, ATR 法を用いて検出しようと試みた。な抢, 本実験で使用した酸化处理をした繊維は, 群馬大学工業 短期大学部の太田教授より提供していただいたあのであ る。ATR プリズムは，ゲルマニウム製，入射角60度， 大きさは, 長さ $50 \mathrm{~mm}$, 幅 $20 \mathrm{~mm}$, 厚さ $2 \mathrm{~mm}$ である。 このプリズムの両面に炭素瀻維をむらなく密着させて, 測定を行なった。検出器は, MCT を用いた。酸化処理 をほどてした繊維と未処理の繊維について，それぞれ 400 回ずつ積算して ATR スペクトルを測定した。処理繊維 のスペクトルから, 未处理絾維のスペクトルを差し引い たあのを，Fig. 17亿示す。 $1720 \mathrm{~cm}^{-1}$ にカルボニル基に よると考えられる吸収が見える。 $1200 \mathrm{~cm}^{-1}$ 付近の幅の 広いピークは, 試料の吸収によるものなのか, ベースラ 
インの歪なのかまだはっきりしていない。 $1600 \mathrm{~cm}^{-1}$ の ピークは, 試料の吸収によるあのであるが, 帰属は現在 検討中である。乙のように筆者らの現状は大変初期的で はあるが，酸化によって導入されたカルボニル基を検出 できたので，今後改善を行なっていきたいと考えている。

\section{5. むすび}

一昔前, FT-IR は大変高価な機械で, 炭素材料の研 究者にとっては高嶺の花であった。しかし最近では，低 価格の装置が市販されるようになり，従来までの分散型 分光器にとって変わられつつある。今後, FT - IR は, 炭素材料の研究者にとってあますます身近なすのとなっ ていくであろう。本稿では, 炭素前駆体である「黒あの」 の赤外線吸収スペクトルを測定する際の実験的方法に一 いて，特に筆者らが実際に使用している，あるいは，使 用したてとがある測定法に限定して解説した。そのため， 内容がかたよっているとの印象を与えるかもしれない。 FT-IR による一般の材料分析で使われている高感度測 定法, 微小微量試料測定法, 発光法などは紙面の都合も あり割愛した。学生や, 若い研究者, 技術者の方々が, あたらしくFT-IRを使って「黒すの」のスペクトルを 測定してみようというときに本稿が少しであ参考になれ ば幸いである。

\section{謝辞}

本稿の内容は，筆者らと (株) コベルコ科研有機分析室 の大西美和子, 古川憲治両氏とで共同で行なっている 「FT - IR によるピッチ類の評価法の検討」の結果の一部 に基づいて，筆者らの責任でまとめたものである。本稿 執筆に際し，スペクトルの測定に協力していただいた両 氏に，乙の場を借りて感謝の意を表わしたい。

\section{文献}

1) 炭素材料学会編，「炭素材料実験技術 1 」，科学技 術社 (1978) 8 章。

2) 平石次郎編「日本分光学会測定法シリーズ 10 フーリエ変換型赤外分光法一化学者のための FTIR」 学会出版センター (1985).

3) 田隅三生「FT-IR の基礎と実際」東京化学同 人 (1986).

4) J.K. Brown, J. Chem. Soc. 744, 752 (1955).

5) J.G. Speight, Appl. Spectrosc. Rev. 5, 211 (1971).

6) P.C. Painter, R.W. Snyder, M. Starsinic, M.M. Coleman, D.W. Kuehn, and A. Davis, Appl. Spectrosc. 35,475 (1981).

7) 例えば日本語版では, 中西香爾, P.H. Solomon, 古舘信生,「赤外線吸収スペクトル」南江堂 (1960). が少し古いが手でろである。

8) 英語版では, D. Dolphin and A. Wick, “Tabulation of Infrared Spectral Data" JohnWiley \& Sons, Inc. (1977). が詳しい。

9) 横野, 真田, 炭素 1981 [No. 105] 73.

10) C. Wang, Fuel 66, 840 (1987).

11) 鈴木，西澤 第14回炭素材料学会年会 $1 \mathrm{~A} 14$ (1987).

12) M. Kaihara, H. Mametsuka, N. Gunji, and Y. Gohshi, J. Spectrosc. Soc. Jpn. 38, 36 (1989).

13) M. Kaihara, H. Mametsuka, N. Gunji, and Y. Gohshi, TANSO 1989 [No. 137] 88.

14) 日本化学会編「新実験化学講座 4 基礎技術 3 光, [II]」丸善 (1976) p. 395.

15) H. Ishida Ed. "Intefaces in Polymer, Ceramics, and Metal Matrix Composites" Elsevier (1988) p. 163. 